\title{
WHAT WERE THE REASONS FOR THE RAPID LANDSLIDE OCCURRENCE IN "PIASECZNO” OPEN PIT? - ANALYSIS OF THE LANDSLIDE PROCESS
}

\author{
JOANNA JAKÓBCZYK, MAREK CAŁA, AGNIESZKA STOPKOWICZ \\ AGH University of Science and Technology, al. Mickiewicza 30, 30-059 Kraków, Poland, \\ e-mail: jjakob@agh.edu.pl, cala@agh.edu.pl, agnieszka.stopkowicz@agh.edu.pl
}

\begin{abstract}
Landslides are major natural hazards occurring in opencast mining. The problem of slope stability failure in the existing open pit mines as well as in those which are at a stage of technical closure is current issue in Poland and all over the world. This problem requires conducting in-depth and meaningful analysis which will identify the causes of processes characterized by a very rapid course and large extent.

The paper presents the analysis of the landslide causes, which took place on May 11, 2011 on the western slope of the internal dump in "Piaseczno" sulphur mine (at a stage of technical closure). It was the first native sulphur open pit mine in Poland in which the exploitation was carried out from 1958 untill 1971. Reclamation works have been ongoing since 2005. The aim of these works is to create water body which will be used for recreational purposes. During the reclamation works on the western slope of "Piaseczno" reservoir the landslide processes were activated. A detailed description of geology and preliminary analyses of landslide processes are given in [1]. The development of landslide took place in a very violent manner. Moreover, the occurrence of the landslide caused the movement of the reservoir shoreline by about 350 meters and created a bay with the area of approximately 6 hectares. Displacement of $600000 \mathrm{~m}^{3}$ of soil masses under the water resulted in its level rising by $56 \mathrm{~cm}$. The total volume of ground masses was over 1 million $\mathrm{m}^{3}$.

The analysis of the landslide process activation was carried out for two representative cross-sections of the internal dump. Numerical calculations were performed using the Limit Equilibrium Method (SLOPE/W GeoStudio) and the Finite Difference Method using the Shear Strength Reduction Method (FLAC Slope). They were aimed at determining the shape and extent of potential slip surface, which would correspond to the observed landslide. The purpose of the analysis, the results of which are presented in the article, was to define how the process proceeded and what factors contributed to its activation.
\end{abstract}

Key words: landslide, open pit mine, slope stability analysis, numerical modelling, Limit Equilibrium Method (LEM), Shear Strength Reduction Method (SSRM)

\section{INTRODUCTION}

On May 11, 2011 around 1 p.m. on the western slope of the internal dump of "Piaseczno" sulfur mine a very rapid and tragic landslide occurred that covered the area of approximately 6 hectares [2]. The landslide caused the movement of the reservoir shoreline by about 350 meters and created a bay with the area of approximately 6 hectares. The displacement of 60 thousands $\mathrm{m}^{3}$ of soil masses under the water resulted in its level rising by $56 \mathrm{~cm}$. Moreover, as a consequence of the landslide, two bulldozers were caught by landslide masses and the operator of one of them has never been found [2].

Similar disasters, both in terms of size and impact took place in open-pit mines in many countries, in- cluding Germany and Greece [3], [4]. These flows had some distinctive characteristics different from the widely documented landslides. Generally, this kind of phenomena happens rapidly in a very short time, usually around one minute. There are no signs that might announce the impending catastrophe, such as cracks, slits or uplifts. Even very old slope can be liquefied. The phenomenon starts from the base of the slope and follows up its upper parts. In addition, a landslide covers a very large area with a length of several hundred meters. These slopes are characterized by a very small angle of inclination (less than $8^{\circ}$ ) - usually between $3^{\circ}$ to $5^{\circ}$, and for saturated parts - even smaller than $3^{\circ}$. Another very characteristic phenomenon, which is observed after the completion of landslide processes, is the water leakage from the ground masses. 
Due to the scale of the landslide in "Piaseczno" sulfur mine (at a stage of technical closure) and its characteristic features, explanation of the reasons for its occurrence was very important. The knowledge of the factors which had influence on the landslide process may prevent similar disasters in the future.

\section{THE PRESENT AND THE PAST OF "PIASECZNO" SULPHUR MINE}

In the early 1950s in Piaseczno and Machów large deposits of native sulphur were discovered and the exploitation was planned using opencast method. In 1953 the construction of the first open pit sulphur mine was started. The mining capacity was estimated at about 3 million tonnes of ore per year. The exploitation began in 1958 and completed in 1971 due to the exhaustion of the bed. In 1972 the exploitation of Tertiary quartz sands, suitable for glass production, was started. Works were carried out untill 1982.

Ore extraction from opencast mines and solution mining were the main methods of sulphur production in Poland. In spite of its high environmental impact, the total extraction from "Piaseczno" and "Machów" excavations was about 82 million $\mathrm{Mg}$ of sulphur ore
[5]. Reclamation works of "Piaseczno" sulphur mine started in 2005 and it have not been finished yet. The aim of these works is to create water body with the area of 160 hectares and 44 meters in depth which will serve recreational purposes. The works included isolation of the outcrop of Tertiary layers using the cover of silt layer and shaping the slope angle to its stability in conditions of filling the tank with water [1]. In September 2009, pit dewatering had been switched off and thus the process of filling the tank with water from natural tributaries began [2].

\section{THE CHARACTERIZATION OF THE LANDSLIDE}

On May 11, 2011 around 1 p.m. landslide processes were activated on the western slope of "Piaseczno" tank. The landslide was initiated with sudden collapsing of soils behind push dozer which moved ground masses in the tank direction. The development of the landslide took place in a violent manner, causing progressive upward and sideways slope collapse before push dozer working above. The occurrence of the landslide caused the movement of the reservoir shoreline by about 350 meters and created a bay with the area of
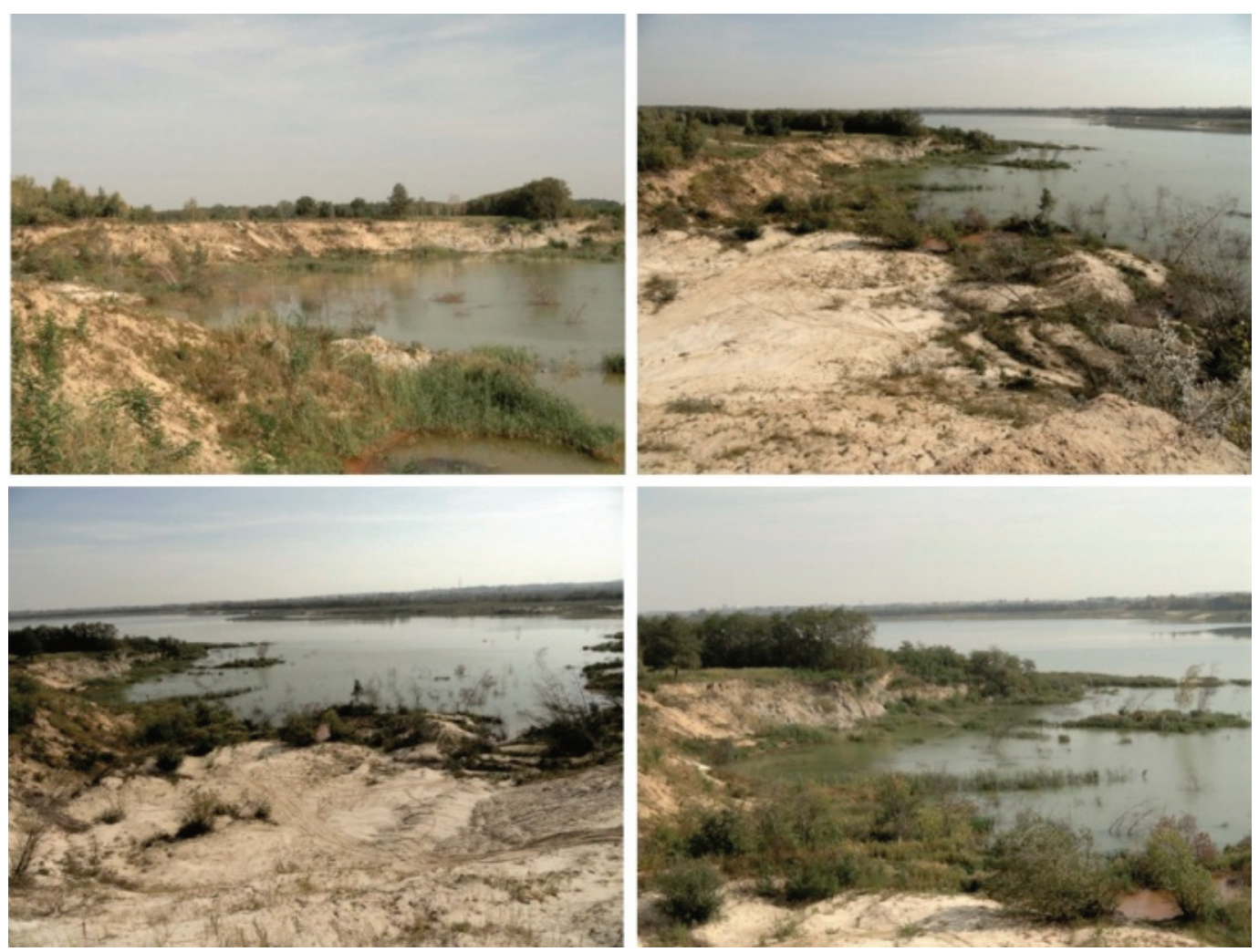

Fig. 1. State of the slope after the formation of the landslide

(Source: photo by J. Jakóbczyk) 
approximately 6 hectares. The range of the landslide is presented with red line in Fig. 2. As a result of this phenomenon the water level rose by $56 \mathrm{~cm}$ - approximately $600000 \mathrm{~m}^{3}$ of soil masses were displaced under the water. The total volume of ground masses was estimated to be over 1.0 million $\mathrm{m}^{3}$ in the initial period of movement. Figure 1 shows the state of the slope after the occurrence of the landslide.

\section{GEOMETRY \\ AND GEOLOGICAL STRUCTURE OF THE WESTERN SLOPE}

Two cross-sections: $1-1^{\prime}$ and $2-2^{\prime}$ were chosen for the analysis. Their location on the map is shown in Fig. 2.
The geometry of the chosen cross-sections was developed on the basis of a detailed geodesic survey. The geological structure was determined from archival drilling, static probe CPTU soundings (calculation of the degree of compaction for non-cohesive soils and the degree of plasticity for cohesive soils) and additional drilling carried out for the analysis. Triaxial tests for soil samples were also made. As a result total friction angle and total cohesion were calculated, taking into account the rapid process of the landslide. Table 1 contains the design values of total geotechnical parameters of soil layers building the western edge of "Piaseczno" tank, which have been adopted in the numerical model. It is worthphile to note that this analysis concerns the dump soils, which are very inhomogeneous and unpredictable, because of the way in which they had been deposited. Consequently, it is

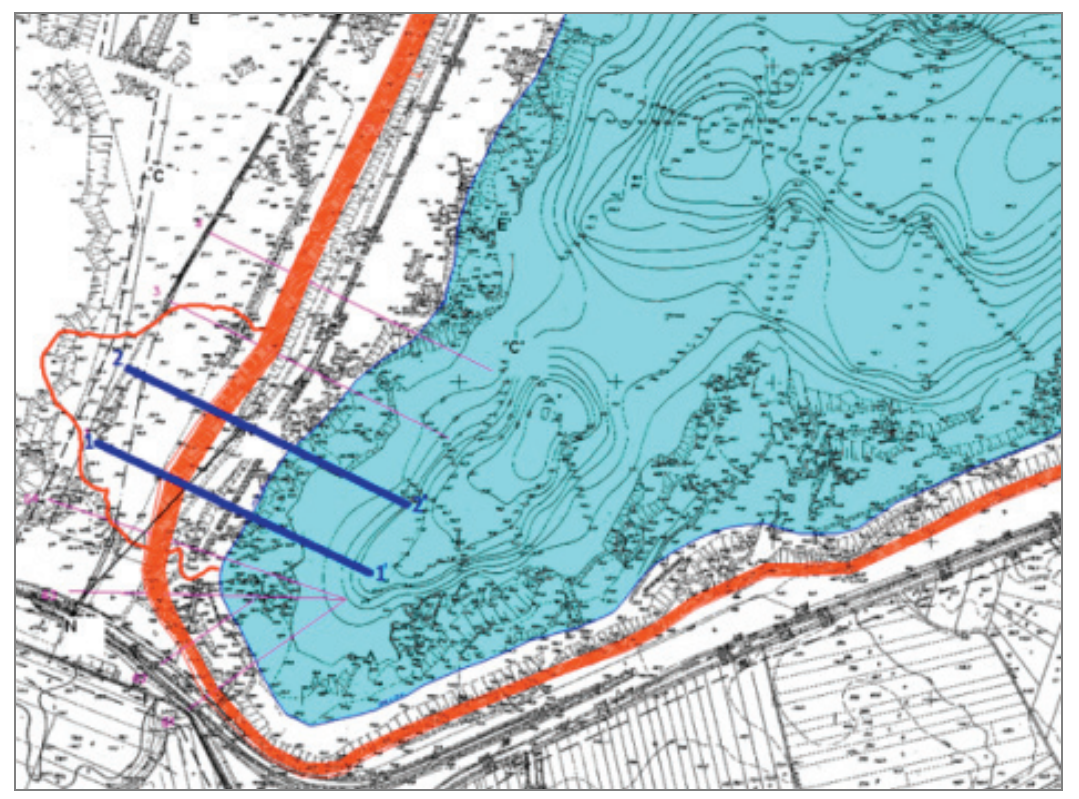

Fig. 2. Documentary map of selected range of the landslide (red line) and the location of the analysed cross-sections 1-1' and 2-2' (blue lines) (Source: prepared on the basis of [2])

Table 1 . The design values of total geotechnical parameters adopted for the numerical analysis for soil layers that build the western slope (Source: own calculations based on [2])

\begin{tabular}{|l|c|c|c|c|}
\hline \multicolumn{1}{|c|}{ Geotechnical layer } & $\begin{array}{c}\text { Color in the } \\
\text { cross-sections }\end{array}$ & $\begin{array}{c}\text { Unit weight } \\
\gamma\left[\mathrm{kN} / \mathrm{m}^{3}\right]\end{array}$ & $\begin{array}{c}\text { Friction angle } \\
\varphi_{u}\left[{ }^{\circ}\right]\end{array}$ & $\begin{array}{c}\text { Cohesion } \\
c_{u}[\mathrm{kPa}]\end{array}$ \\
\hline Subsoil & & 20.0 & 32.0 & 0.0 \\
\hline Silt & & 19.5 & 5.5 & 25.0 \\
\hline Sand P1 & & 18.0 & 8.5 & 15.0 \\
\hline Sand P2 & & 18.0 & 8.5 & 15.0 \\
\hline Clay & & 18.0 & 8.5 & 15.0 \\
\hline Aggradate Mud & 15.0 & 2.0 & 15.0 \\
\hline $\begin{array}{l}\text { Quartz sands } \\
\text { (suitable for glass production) }\end{array}$ & & 18.0 & 33.0 & 2.0 \\
\hline
\end{tabular}




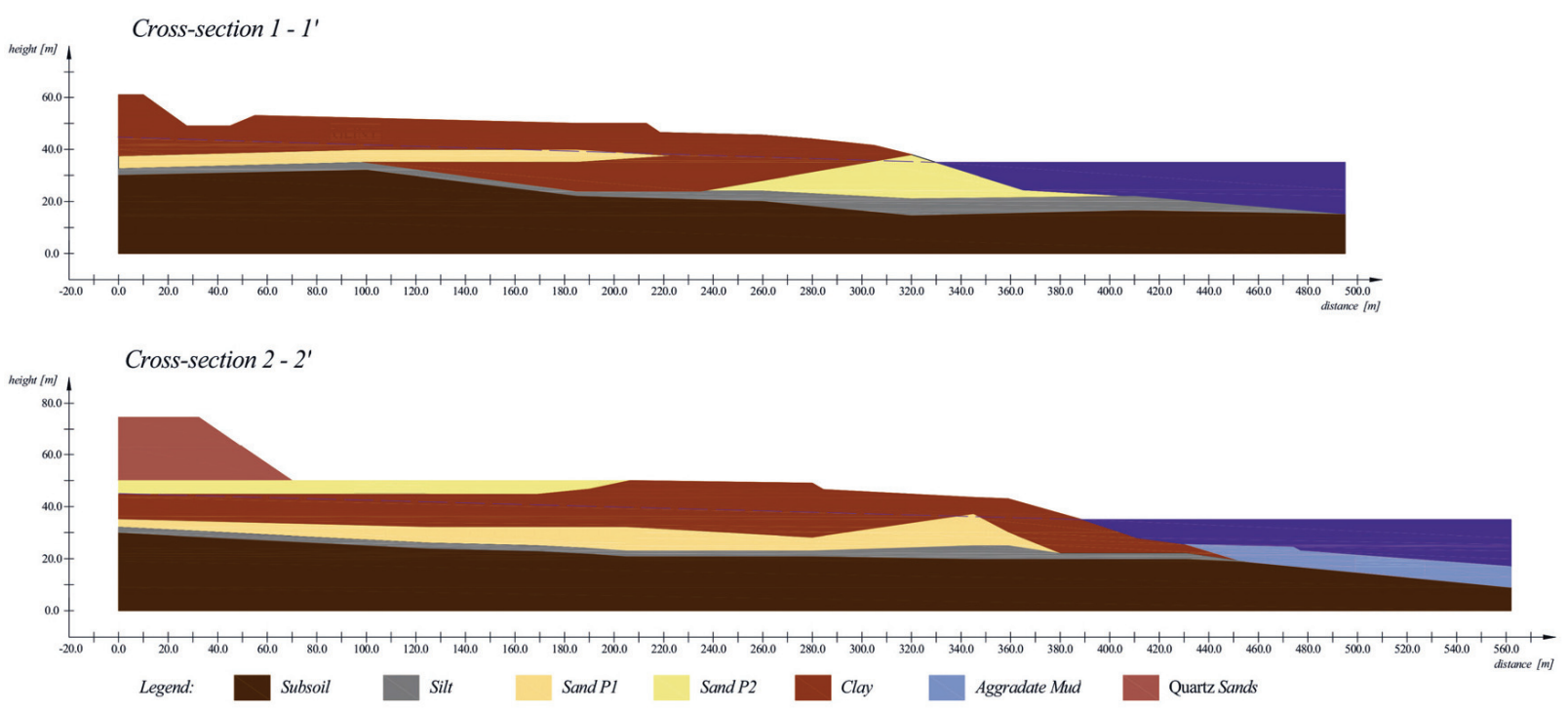

Fig. 3. The geometry and geological structure for the cross-sections 1-1' and 2-2' (Source: figures by J. Jakóbczyk [6])

very difficult to evaluate their geotechnical parameters.

Figure 3 shows the geometry and geological structure of the individual cross-sections.

\section{NUMERICAL ANALYSIS OF THE WESTERN SLOPE STABILITY}

Numerical analysis of slope stability in the western sections $1-1^{\prime}$ and $2-2^{\prime}$ was intended to clarify the reasons for the landslide activation in the area. Numerical calculations have been made in the program SLOPE/W GeoStudio, based on the Limit Equilibrium Method (Bishop, Janbu and Morgenstern - Price's methods) and three methods of searching the potential slip surface: Auto Locate, Entry and Exit and Fully Specified. For comparison, an analysis was performed using FLAC Slope, based on the Finite Difference Method using the Shear Strength Reduction Method. In addition, contour maps showing the zones of the factor of safety (FS) values were made with the use of FLAC 3D. The exact calculation results are shown in work [6].

The analysis was carried out in three steps [6]:

- Step 1 - calculations of preliminary geotechnical parameters of the layers (listed in Table 1).

- Step 2 - calculations of the reduced geotechnical parameters of the clays layer (cohesion value was reduced).

- Step 3 - calculations for a staged course of landslides (two-step course of the landslide was examined).

\subsection{SLOPE STABILITY ANALYSIS IN CROSS SECTIONS 1-1' AND 2-2'}

The stability analysis of cross-sections 1-1' and 2-2' was made assuming their geometry (Fig. 3) and values of the geotechnical parameters presented in Table 1. Based on [1], it was noticed that the water table in the excavation is 35.0 meters above the sea level (Fig. 4).

The slope in the cross-sections concerned was characterized by a height of 46.0 meters to the highest point of the slopes crown in section 1-1' and $58.0 \mathrm{~m}$ in section $2-2^{\prime}$. The general value of the slope angle in cross-section $1-1^{\prime}$ was about $7^{\circ}$ and in cross-section $2-2^{\prime}$ about $6^{\circ}$. Model length and height of about 495.0 and 61.0 meters (respectively) was considered in cross-section 1-1' and 562.0 and 74.6 meters (respectively) in cross-section 2-2'.

The numerical calculations were performed in the first place for the lower part of the slope, which was located in close proximity to the excavation. The analysis was obtained by Auto Locate method (SLOPE/W GeoStudio) and the Shear Strength Reduction Method (FLAC Slope). The factors of safety (FS) values do not exceed 1.5 for section $11^{\prime}$ or slightly exceed this value for section $2-2$, which indicates that occurrence of the landslide was unlikely or very unlikely (Tables 2,3 ).

The aim of further calculations was to identify the slip surface, which will cover the entire slope and have the shape similar to that of the observed landslide. The FS values, which were calculated for these 


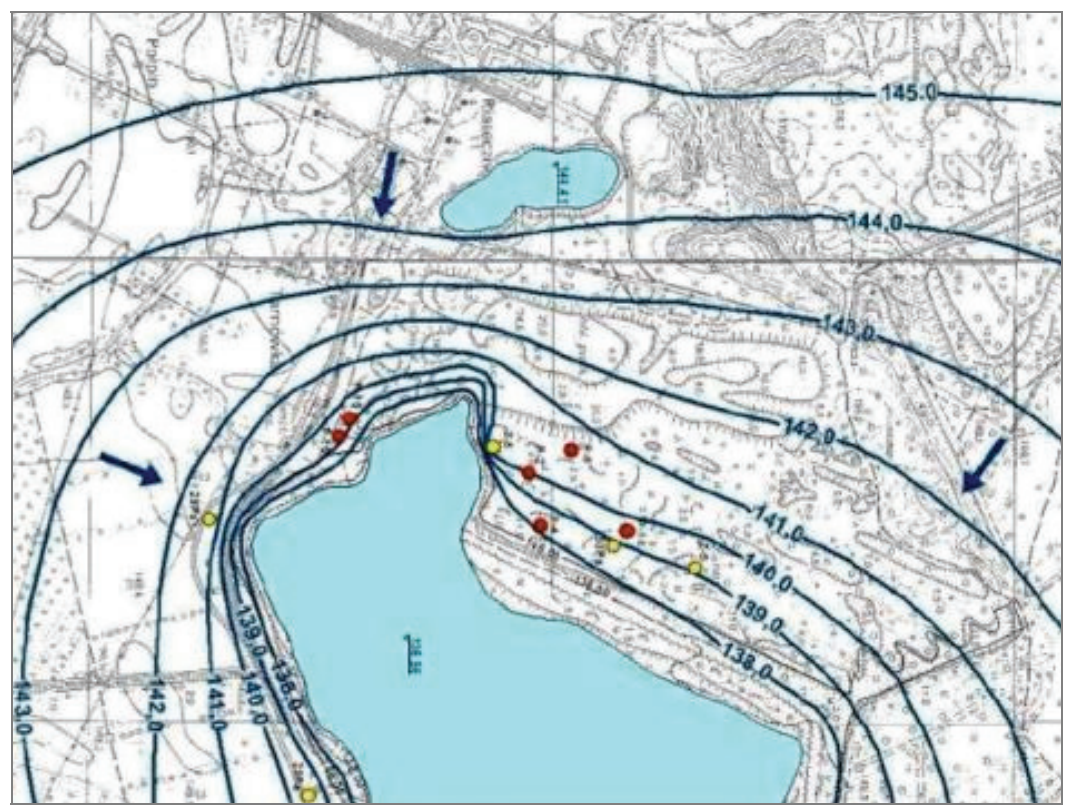

Fig. 4. Location of groundwater level Quaternary aquifer in the western part of "Piaseczno" reservoir - as of July 2011 (Source: [2])

Table 2. Summary of the results of numerical calculations for cross-section 1-1' (Source: prepared by J. Jakóbczyk based on own calculations [6])

\begin{tabular}{|c|c|c|c|c|}
\hline \multirow{2}{*}{ Test coverage of landslides } & \multicolumn{3}{|c|}{$\begin{array}{l}\text { Limit Equilibrium Method } \\
\text { - SLOPE/W GeoStudio }\end{array}$} & \multirow{2}{*}{$\begin{array}{c}\text { The Shear Strength Reduction } \\
\text { Method - FLAC Slope }\end{array}$} \\
\hline & $\begin{array}{l}\text { Bishop } \\
\text { method }\end{array}$ & $\begin{array}{l}\text { Janbu } \\
\text { method }\end{array}$ & $\begin{array}{l}\text { Morgenstern } \\
\text {-Price method }\end{array}$ & \\
\hline \multicolumn{5}{|c|}{ FIRST STEP - initial geotechnical parameters } \\
\hline \multirow{2}{*}{ The lower parts of the slopes } & \multicolumn{3}{|c|}{ Auto Locate method } & \multirow{2}{*}{1.46} \\
\hline & 1.496 & 1.448 & 1.494 & \\
\hline \multirow{4}{*}{ The higher parts of the slopes } & \multicolumn{3}{|c|}{ Entry and Exit method } & \multirow{4}{*}{1.89} \\
\hline & 1.887 & 1.868 & 1.885 & \\
\hline & \multicolumn{3}{|c|}{ Fully Specified method } & \\
\hline & 2.468 & 2.064 & 2.086 & \\
\hline \multicolumn{5}{|c|}{ SECOND STEP - modified geotechnical parameters (cohesion value for silt layer reduced) } \\
\hline \multirow{2}{*}{ The lower parts of the slopes } & \multicolumn{3}{|c|}{ Auto Locate method } & \multirow{2}{*}{0.87} \\
\hline & 0.949 & 0.921 & 0.987 & \\
\hline \multirow{4}{*}{ The higher parts of the slopes } & & and Exi & thod & \multirow{4}{*}{1.60} \\
\hline & 1.600 & 1.590 & 1.598 & \\
\hline & \multicolumn{3}{|c|}{ Fully Specified method } & \\
\hline & 1.770 & 1.499 & 1.517 & \\
\hline \multicolumn{5}{|c|}{ THIRD STEP - a two-step course of landslides } \\
\hline \multirow{2}{*}{ The higher parts of the slopes } & \multicolumn{3}{|c|}{ Entry and Exit method } & \multirow{2}{*}{1.01} \\
\hline & 1.062 & 1.047 & 1.061 & \\
\hline
\end{tabular}

assumptions (using Entry and Exit method, Fully Specified method - SLOPE/W GeoStudio and the Shear Strength Reduction Method - FLAC Slope), were close to 2.0 (Tables 2,3). The data indicate that the formation of landslide of this kind of shape and coverage is very unlikely under the values of geotechnical parameters of soil layers. Due to the previous fact, the cohesion of the silt layer was reduced from the value of $25.0 \mathrm{kPa}$ to $10.0 \mathrm{kPa}$ recognizing that this layer is the most sensitive to water (because of the presence of clay minerals) which could influence the reduction of its parameters. Friction angle value remained unchanged, because for cohesive soils such as clay or silt (which have relatively low value of friction angle) cohesion is the main parameter which has influence on the shear strength. The saturation could also 
Table 3. Summary of the results of numerical calculations for cross-section 2-2'

(Source: prepared by J. Jakóbczyk based on own calculations [6])

\begin{tabular}{|c|c|c|c|c|}
\hline \multirow{2}{*}{ Test coverage of landslides } & \multicolumn{3}{|c|}{$\begin{array}{l}\text { Limit Equilibrium Method } \\
\text { - SLOPE/W GeoStudio }\end{array}$} & \multirow{2}{*}{$\begin{array}{c}\text { The Shear Strength Reduction } \\
\text { Method - FLAC Slope }\end{array}$} \\
\hline & $\begin{array}{l}\text { Bishop } \\
\text { method }\end{array}$ & $\begin{array}{l}\text { Janbu } \\
\text { method }\end{array}$ & $\begin{array}{l}\text { Morgenstern } \\
\text {-Price method }\end{array}$ & \\
\hline \multicolumn{5}{|c|}{ FIRST STEP - initial geotechnical parameters } \\
\hline \multirow{2}{*}{ The lower parts of the slopes } & \multicolumn{3}{|c|}{ Auto Locate method } & \multirow{2}{*}{1.59} \\
\hline & 1.594 & 1.544 & 1.592 & \\
\hline \multirow{4}{*}{ The higher parts of the slopes } & \multicolumn{3}{|c|}{ Entry and Exit method } & \multirow{4}{*}{1.85} \\
\hline & 1.913 & 1.887 & 1.911 & \\
\hline & \multicolumn{3}{|c|}{ Fully Specified method } & \\
\hline & 2.283 & 1.820 & 1.853 & \\
\hline \multicolumn{5}{|c|}{ SECOND STEP - modified geotechnical parameters (cohesion value for silt layer reduced) } \\
\hline \multirow{2}{*}{ The lower parts of the slopes } & \multicolumn{3}{|c|}{ Auto Locate method } & \multirow{2}{*}{0.89} \\
\hline & 1.384 & 1.346 & 1.182 & \\
\hline \multirow{4}{*}{ The higher parts of the slopes } & \multicolumn{3}{|c|}{ Entry and Exit method } & \multirow{4}{*}{1.63} \\
\hline & 1.653 & 1.639 & 1.652 & \\
\hline & \multicolumn{3}{|c|}{ Fully Specified method } & \\
\hline & 1.701 & 1.384 & 1.416 & \\
\hline \multicolumn{5}{|c|}{ THIRD STEP - a two-step course of landslides } \\
\hline \multirow{2}{*}{ The higher parts of the slopes } & \multicolumn{3}{|c|}{ Fully Specified method } & \multirow{2}{*}{1.07} \\
\hline & 1.178 & 0.997 & 1.019 & \\
\hline
\end{tabular}

affect the activation of landslide movements. Other assumptions used in the calculations remained unchanged.

After reduction of the cohesion value of silt layer from $25.0 \mathrm{kPa}$ to $10.0 \mathrm{kPa}$, the calculation was carried out analogously as in the previous step. In this case, the Auto Locate method (SLOPE/W GeoStudio) and the Shear Strength Reduction Method (FLAC Slope) were used. It should be pointed out that during the calculation of FS value, both the friction angle and cohesion values are progressively reduced.
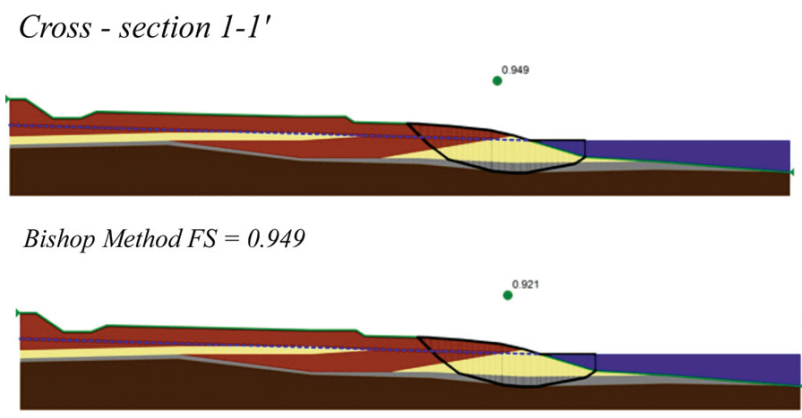

Janbu Method FS $=0.921$

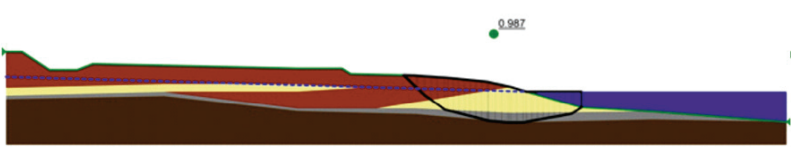

Morgenstern - Price Method FS $=0.987$
The factors of safety (FS) for the lower edge of section 1-1' does not exceed the value of 1.0 , and for section 2-2' the value of 1.4 (SLOPE/W GeoStudio) and 1.0 (FLAC Slope) (Figs. 5-7 and Tables 2, 3). As a result, it can be concluded that the slope is in the equilibrium limit state and the landslide is likely to be activated in this area. In the second step, the FS values were calculated for the slip surface which covers the whole slope and has shape similar to the resulting landslides. Entry and Exit method and Fully Speci-

Cross - section 2-2'

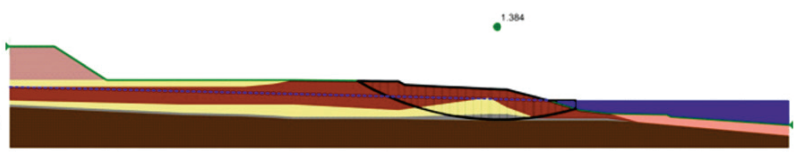

Bishop Method FS = 1.384

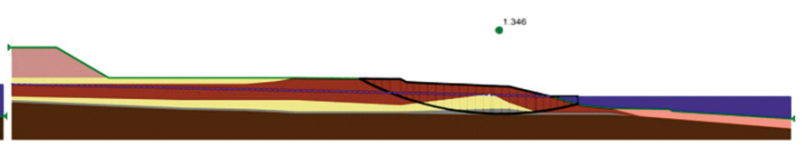

Janbu Method FS = 1.346

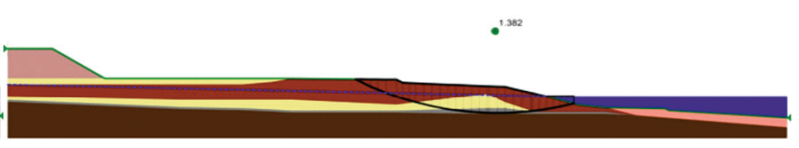

Morgenstern - Price Method FS $=1.382$

Fig. 5. The results of stability calculations in cross-section 1-1' and 2-2' for silt cohesion reduced to $10.0 \mathrm{kPa}$ obtained using Auto Locate method (Source: prepared by J. Jakóbczyk based on own calculations [6]) 


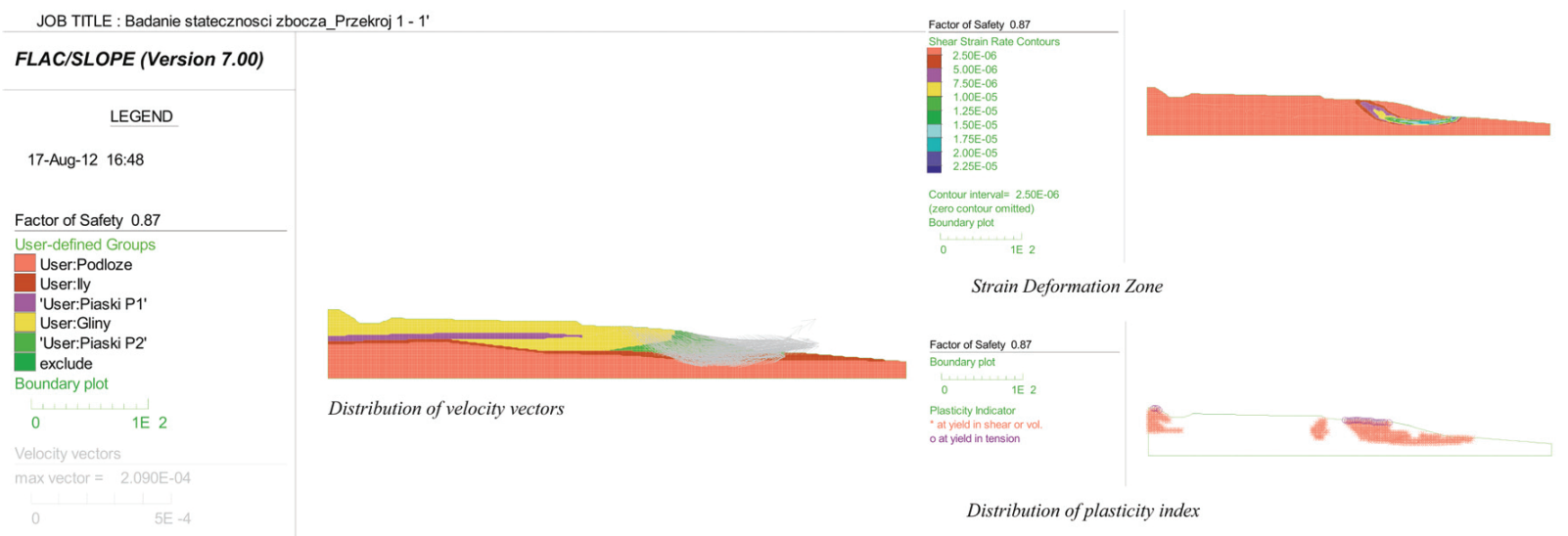

Fig. 6. The results of stability calculations in cross-section 1-1' for silt cohesion reduced to $10.0 \mathrm{kPa}$ obtained using the Finite Difference Method (Source: prepared by J. Jakóbczyk based on own calculations [6])

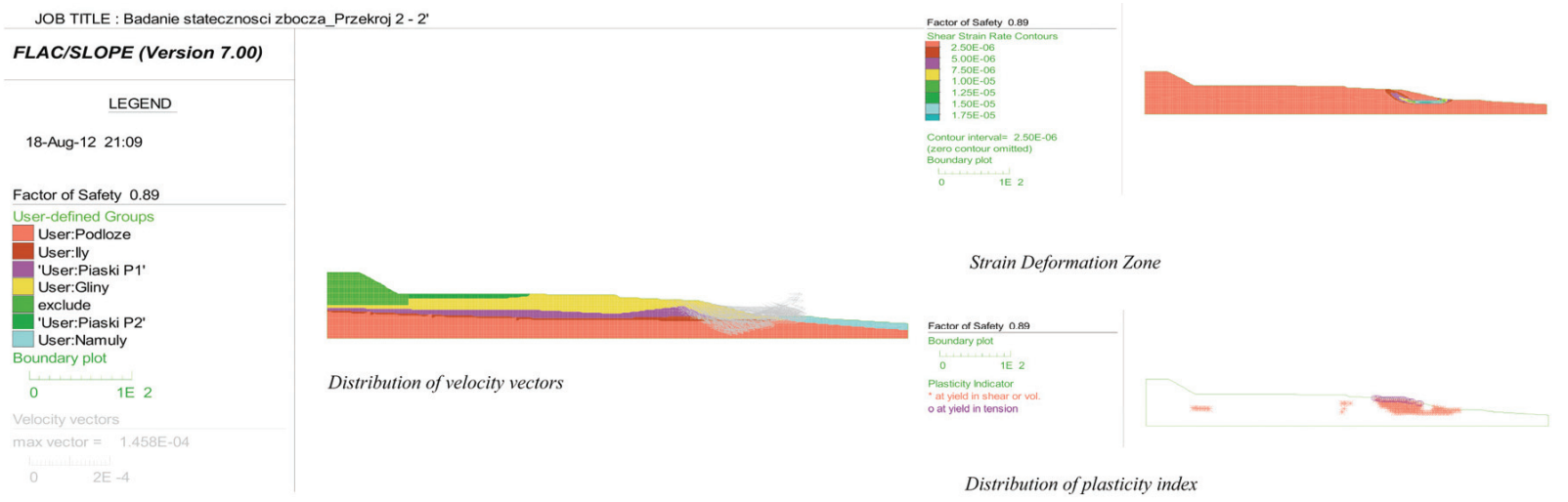

Fig. 7. The results of stability calculations in cross-section 2-2' for silt cohesion reduced to $10.0 \mathrm{kPa}$ obtained using the Finite Difference Method (Source: prepared by J. Jakóbczyk based on own calculations [6])

fied method were used (SLOPE/W GeoStudio) for that purpose. The FS values ranged from 1.5 to 2.0 (Tables 2,3). The same range of values was obtained from the analysis carried out with the Finite Difference Method (FLAC Slope). Consequently, it is clear that under these conditions of geometric and geotechnical parameters, the occurrence of such large landslide is very unlikely.

Taking into consideration that the lower part of slope is (as analysis shows) in the equilibrium limit state, a computational model which assumed that the landslide proceeded in two stages was built. In the first stage the landslide covered the lowest part of the slope. The shape of the slip surface had been adopted in accordance with the result obtained using the Auto Locate method (Morgenstern-Price method) with modified value of cohesion for the silt layer (Fig. 5). Other assumptions were not changed.

Assuming a two-stage course of the landslide it was assumed that in the first stage there was a decline in stability of the lower part of the slope, whereby part of the massif moved into the tank. Thus, the upper part of the slope lost support surface and also reached the equilibrium limit state. Analysing the results, it can be concluded that after shaping surface of the lower part of the slope in accordance with the slip surface obtained from the calculation by Auto Locate method (Morgenstern-Price method), the Entry and Exit method (SLOPE/W GeoStudio) and the Shear Strength Reduction Method (FLAC Slope) gave the FS values close to 1.0 (Figs. 8-10 and Tables 2, 3). The shape of the slip surfaces corresponds to the actual surface of rupture in both cross-sections 1-1' and 2-2'. As a result, it is clear that the whole hillside had been in the limit equilibrium state and the formation of landslides was likely.

Based on the above analysis it can be concluded that the landslide in cross-sections $1-1^{\prime}$ and $2-2^{\prime}$ was caused by the reduction of geotechnical parameters of silt layers, which were most sensitive to the influence of water. It can also be said that the landslide proceeded in two stages. In the first stage there was 
a decline in stability of the lower part of the slope. In the second stage, the landslide covered almost the entire slope, due to the loss of support and the forma- tion of different geometry escarpment. This mechanism explains the high range and rapidity of the landslide process.

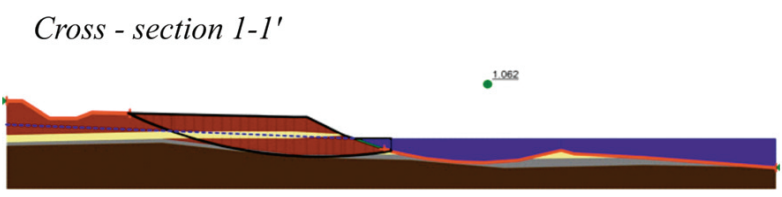

Cross - section 2-2'

Bishop Method FS $=1.062$

Bishop Method FS $=1.178$

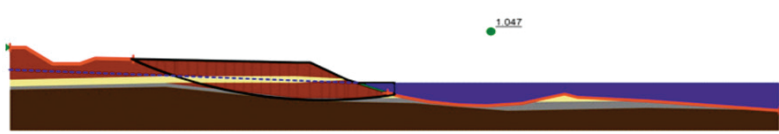

Janbu Method FS $=1.047$

Janbu Method FS $=0.997$

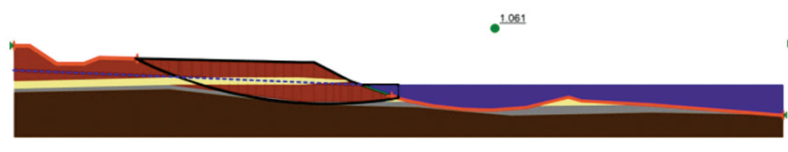

Morgenstern - Price Method FS $=1.061$
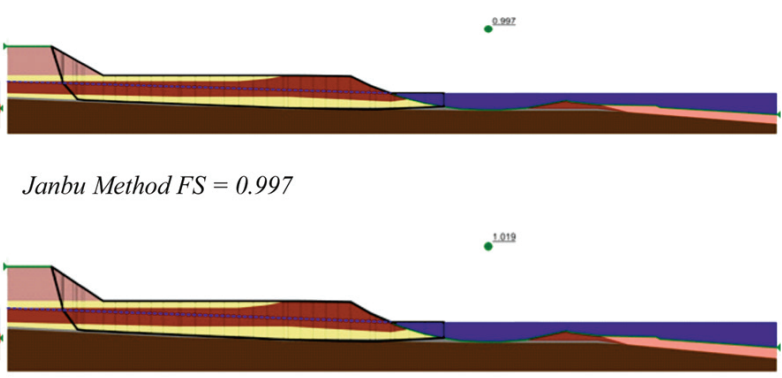

Morgenstern - Price Method FS $=1.019$

Fig. 8. The results of stability calculations in cross-section 1-1' and 2-2' assuming a two-step course of landslides obtained using Entry and Exit method (Source: prepared by J. Jakóbczyk based on own calculations [6])

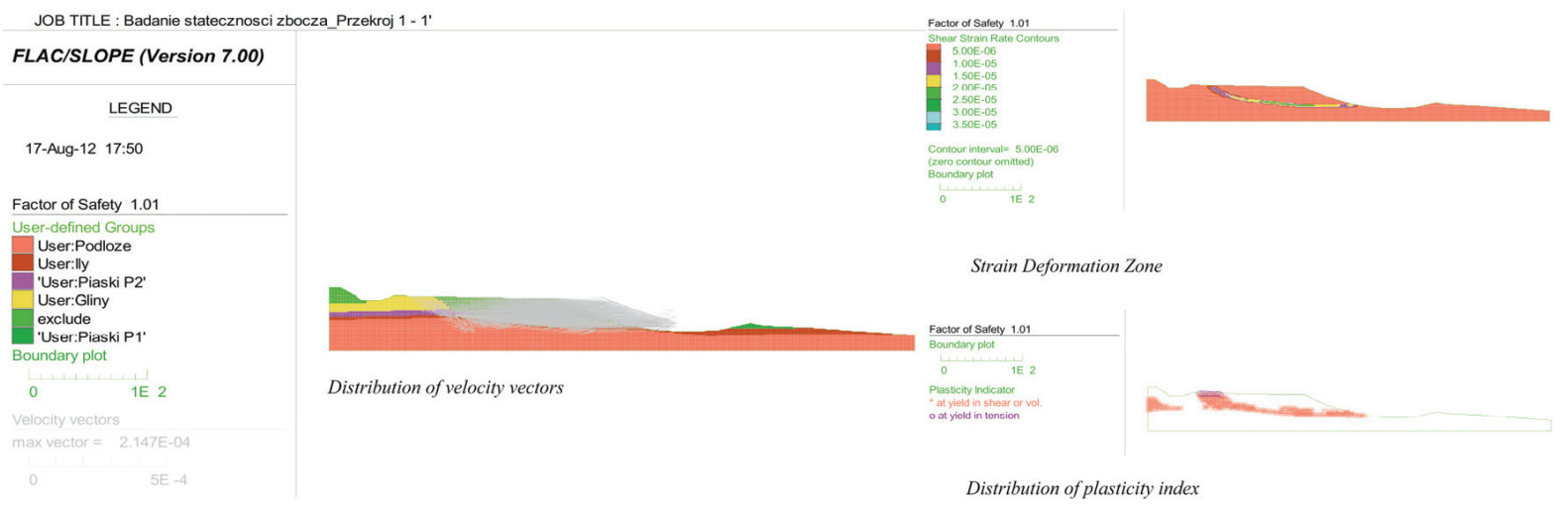

Fig. 9. The results of stability calculations in cross-section 1-1' assuming a two-step course of landslides obtained using the Finite Difference Method (Source: prepared by J. Jakóbczyk based on own calculations [6])
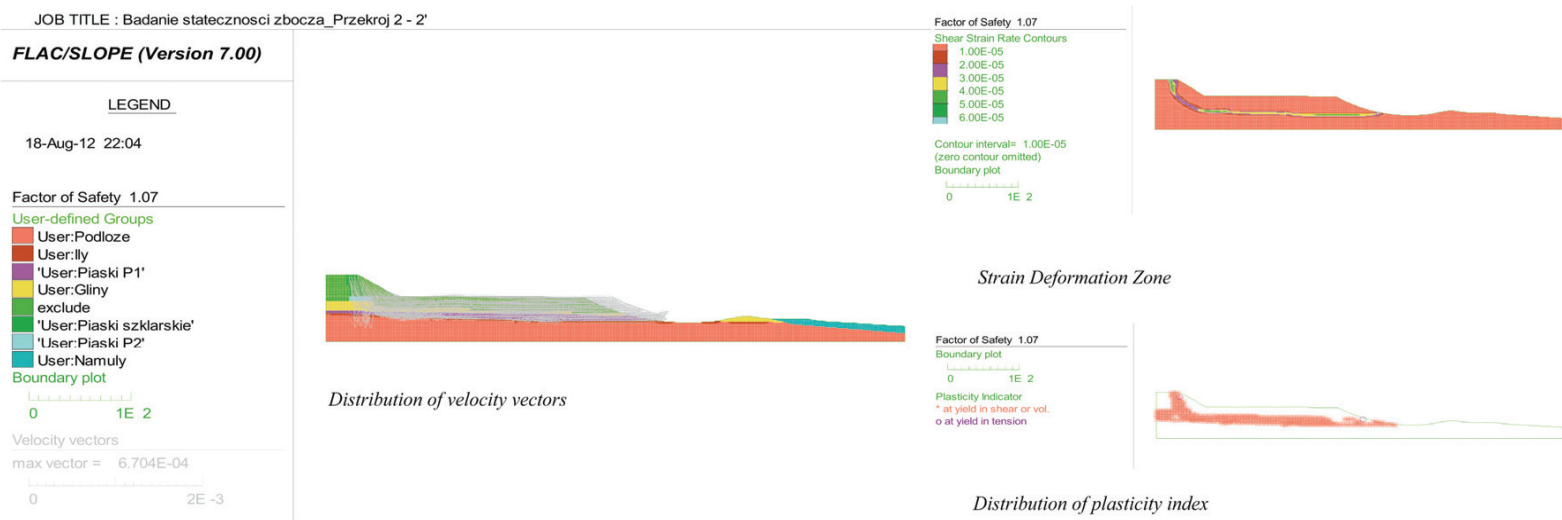

Strain Deformation Zone

Distribution of velocity vectors

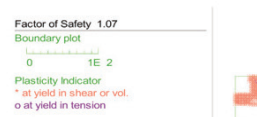

Distribution of plasticity index

Fig. 10. The results of stability calculations in cross-section 2-2' assuming a two-step course of landslides obtained using the Finite Difference Method (Source: prepared by J. Jakóbczyk based on own calculations [6]) 


\subsection{ANALYSIS OF THE RESULTS FROM NUMERICAL CALCULATIONS}

The slope stability analysis in cross-sections $1-1^{\prime}$ and 2-2' was carried out using the Limit Equilibrium Method (SLOPE/W GeoStudio) and the Finite Difference Method (FLAC Slope). The calculations were performed in three steps, which aimed at determination of the most probable mechanism of the landslide process. It was found that the most likely causes of the landslide were the reduction of cohesion value of silt layer, which was most sensitive to the influence of water and stepwise course of the process. On the basis of the results obtained, it can be concluded that the formation of such a large landslide is very unlikely when the one-step course is considered. It should be assumed that the first landslide occurred in the lower part of the slope. Then, as a result of changes in geometry of the slope as well as the additional load and loss of support surface, landslide processes covering such wide area were activated. It should also be noted that the results obtained from the Limit Equilibrium Method analysis and the Finite Difference Method analysis overlapped with each other. It shows that the proper mechanism of the landslide was adopted. It was also confirmed by $3 \mathrm{D}$ numerical calculations presented in [7].

\subsection{CONTOUR MAPS PRESENTING THE ZONES OF THE FACTOR OF SAFETY VALUES}

For the analysed cross-sections 1-1' and 2-2' calculations with use of the FLAC 3D program were also

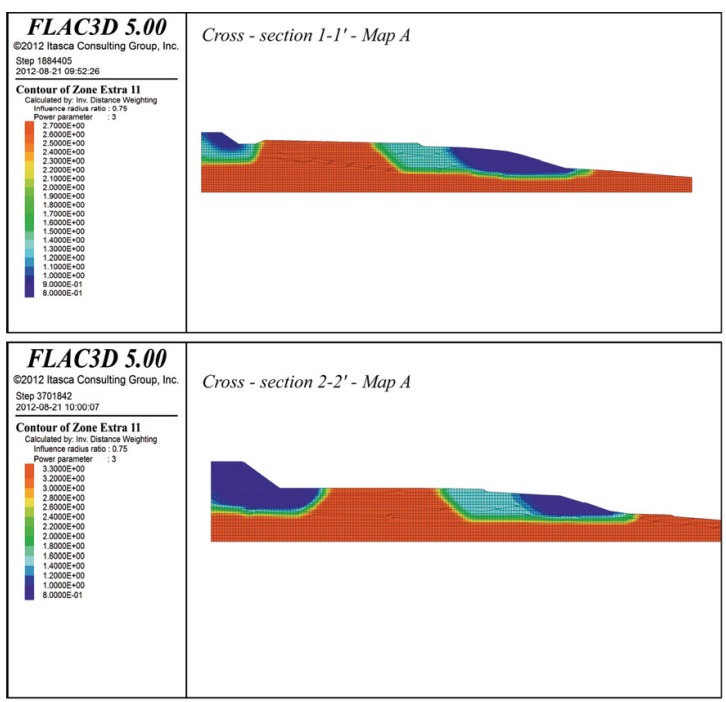

performed. As a result, the contour maps presenting zones of the factor of safety (FS) values were obtained (Fig. 11). The geometry of the cross-sections with separate soil layers and the corresponding values of geotechnical parameters (obtained with the program FLAC Slope) was exported to the program FLAC 3D by adopting a cross-sectional thickness equal to 2.0 meters. Two contour maps were prepared for each crosssection. Maps labelled A were drawn for soil conditions with the reduced cohesion value of silts layer. Maps labeled B included the assumption of the stepwise landslide processes.

\subsection{ANALYSIS OF THE RESULTS FROM THE CONTOUR MAPS}

Contour maps A for the cross-sections 1-1' and 2-2' were prepared for the reduced cohesion value (to $10.0 \mathrm{kPa}$ ) of the silts layer. Based on the maps, it can be concluded that the lowest values of the factor of safety (FS from about 0.8 to 1.0) were obtained for the lowest part of slope as well as for the clays dump (cross-section 1-1') and quartz sands dump (crosssection 2-2') - localised in the highest part of the slope. Zones marked in dark blue are the ones where formation of landslides is very likely. It should be noted that these results overlap the results obtained from the 2D analysis. Taking into consideration the upper part of the slope a light blue zone was obtained. The FS values for this zone do not exceed 1.5 for cross-section 1-1' and 1.8 for cross-section $2-2^{\prime}$, so the occurrence of the landslide covering the area analysed

Fig. 11. Contour maps for cross-sections 1-1' and 2-2' of the individual compartments of the zones of the factor of safety values - for silts cohesion reduced to $10.0 \mathrm{kPa}$ (Map A) and assuming a staged course of the landslide (Map B)

(Source: prepared by J. Jakóbczyk based on own calculations [6]) 
is unlikely or very unlikely. Yellow zone through green to the red one was taken for the parts where the formation of the landslide is very unlikely and the FS value is in the range from 1.5 to 2.7 for cross-section $1-1^{\prime}$, and from 1.8 to 3.3 for the crosssection 2-2'.

Contour maps B prepared for cross-section 1-1' and $2-2^{\prime}$ have assumed a stepwise landslide processes and took into consideration its two stages: the lowest part of the slope had slid first, and then the soil had completely lost its strength as a result of water saturation and decrease in density. Based on the maps it can be seen that the lowest values of the factor of safety (FS from about 0.6 to 1.0 ) were obtained for the lowest part of slope as well as for the clays dump (cross-section 1-1') and quartz sands dump (cross-section 2-2') which are localised in the highest part of the slope, where FS reached values from about 0.8 to 1.0 . Zones marked with dark blue are the zones where formation of landslide is very likely. It should be noted that these results also overlap the results obtained from the $2 \mathrm{D}$ analysis. Light blue colour indicates a zone of the factor of safety (FS) values from 1.0 to about 1.5 for crosssection 1-1' and about 1.4 for cross-section $2-2^{\prime}$. The FS values suggested that the occurrence of the landslide of this magnitude is unlikely. Green zone through yellow to the red one are indicated where the formation of the landslide is unlikely or even very unlikely - the FS value is in the range from 1.5 to 3.0 for cross-section 1-1', and from 1.4 to 2.9 for the cross-section 2-2'.

Assuming a single-step course of landslide, for both cross-sections, the slip surface for which the FS value would be close to 1.0 and whose shape resembles an actual landslide surface was determined. However, the obtained results clearly testify to the decline of the stability in this part of the slope which was nearest to the newly formed edge of the excavation. It is possible that after taking account of the landslide dark blue zone and performing a reanalysis it would appear that the landslide covered the entire range of the slope.

\section{SUMMARY}

The paper presents the analysis of the slope stability in order to answer the question: "What were the reasons for the rapid landslide occurrence in "Piaseczno" open pit?" The analysis was carried out for the two cross-sections located in the area of the landslide oc- currence in order to explain the reasons for its creation. Numerical calculations were performed using the Limit Equilibrium Method (SLOPE/W GeoStudio) and the Finite Difference Method using the Shear Strength Reduction Method (FLAC Slope).

The results of the analysis carried out for the part of the slope covered by landslide showed that it probably proceeded in two stages. In the first stage there was a landslide in the lower part of the slope, which was most exposed to the loss of stability (because of the prevailing equilibrium limit state conditions). Then the landslide reached upper part of the slope, which reached the limit equilibrium state as a result of changes in its geometry. The load from the sands dump was very important at this point. Although, originally the distance from the edge of the slope to the sands dump was about 330 meters (cross-section 1-1') and 380 meters (cross-section 2-2') at the time of completion of the first stage it declined by about 100-150 meters. A very important factor in the formation of the landslide in Piaseczno was ground conditions that turned out to be more complicated than it had been suspected. The presence of the silt layer, which is characterized by layered structure with slippery contact surfaces, became the border through which the slip surface proceeded. The weathering process of the silt layer could cause the decrease in the degree of the plasticity range and already under the influence of a small inflow went into a liquid state. Furthermore, water saturation caused the increase of the soils' unit weight, which resulted in the increase of the force tending to move the ground masses. Also the penetration of water into the silt layer caused its softening that decreased the force acting against the landslide processes. Very important is also the fact that during the entire process of reclamation works the groundwater level in the internal dump was significantly higher than in the reservoir. Flowing water can wash away the fine particles of soil, reducing its resistance to shear. The Sand layer being fuzzy, due to suffosion, lost its load capacity which contributed to the activation of landslide processes. A very rapid progress of the landslide can be explained by the long lasting high water level in the internal dump. Even slight stress could lead the dump soils to a flow because of the low shear strength and the rising hydraulic gradient. The flow, in contrast to a slide or a creep, is that kind of mass wasting where nothing announces its sudden rise. In conclusion, the analysis of the landslide causes revealed that there was not one but a set of factors whose joint action resulted in the tragic disaster. 


\section{CONCLUSIONS}

Pursuing such an important project, connected with the extraction of mineral resources in open pit mines, it is very important to understand the impact of all works to the environment. To reduce the number of such uncontrolled phenomena like landslides, conditions of their formation must be understood. Knowledge of the factors that influence the activation of landslide processes can be very important in conducting mining activities as well as during its technical closure. Keeping for years the conditions which may result in a violent and tragic disaster should not be allowed. Very important is also the knowledge of landslide prevention techniques and the ability to recognize and interpret symptoms which may indicate the loss of the slope stability. It should be pointed out that accurate and detailed diagnosis of soil and water conditions as well as monitoring changes give rise to the proper planning and implementation of mining operations and the elimination of its consequences.

\section{REFERENCES}

[1] Flisiak J., Frankowski Z., Haladus A., Majer E., Kowalski M., PietrZykowski P., RYBicki S., Development and causes of the landslide in a water reservoir escarpment, the former "Piaseczno" sulphur open-cast mine (Rozwój i określenie przyczyn osuwiska na skarpie zbiornika wodnego po od- krywkowej kopalni siarki „Piaseczno”), Przegląd Geologiczny, 2014, 62(4), 190-197. ISSN 0033-2151.

[2] Polish Geological Institute, National Research Institute, Documentation of Geology-Engineering to determine the causes of landslides on the western slope of the Piaseczno tank formed in the internal dump soils of the Piaseczno sulphur mine (Dokumentacja Geologiczno-Inżynierska w celu ustalenia przyczyn powstania osuwiska na zachodniej skarpie zbiornika „Piaseczno” uformowanej w gruntach zwatowiska wewnętrznego bylej kopalni siarki „Piaseczno”), Warsaw 2011, (in Polish).

[3] Steiakakis E., Kavouridis K., Monopolis D., Large scale failure of the external waste dump at the "South Field" lignite mine, Northern Greece, Engineering Geology, 2008, 104 (3-4), 269-279. DOI: 10.1016/j.enggeo.2008.11.008.

[4] Wichter L., Stabilisation of old lignite pit dumps in Eastern Germany, Bulletin of Engineering Geology and the Environment, 2006, 66, 45-5. DOI: 10.1007/s10064-006-0051-4.

[5] Sulphur Mine Machów, (2006), History. Retrieved January, 2012, from http://www.ksmachow.pl/pl/historia,5.html

[6] JАKÓBCZYK J., Analysis of the causes of the landslide occurrence in the excavation of the "Piaseczno" sulphur mine (in a stage of technical closure) (Analiza przyczyn powstania osuwiska $w$ wyrobisku likwidowanej kopalni siarki „Piaseczno"), M.Sc. thesis, AGH University of Science and Technology, Faculty of Mining and Geoengineering, 2012, (in Polish).

[7] Cala M., Von Bismarck F., Illing M., Geotechnical and environmental aspects of reclamation and revitalisation of post-mining areas in Poland and Germany (Geotechnische und Umweltaspekte bei der Rekultivierung und Revitalisierung von Bergbaufolgelandschaften in Polen und in Deutschland - Geotechniczne i środowiskowe aspekty rekultywacji i rewitalizacji obszarów pogórniczych w Polsce $i w$ Niemczech), Wydawnictwa AGH, Kraków 2014, ISBN: 978-83-7464-721-2. 